\title{
Spatial distribution of Bertholletia excelsa in selectively logged forests of the Peruvian Amazon
}

Rockwell, Cara A.; Guariguata, Manuel R.; Menton, Mary; Arroyo Quispe, Eriks; Quaedvlieg, Julia; Warren-Thomas, Eleanor; Fernandez Silva, Harol; Jurado Rojas, Edwin Eduardo; Hideki Kohagura Arrunategui, Jose Andres; Meza Vega, Luis Alberto; Quenta Hancco, Roger; Revilla Vera, Olivia; Valera Tito, Jonatan Frank; Villarroel Panduro, Betxy Tabita; Yucra Salas, Juan Jose

Journal of Tropical Ecology

DOI:

$10.1017 / \mathrm{S} 0266467416000614$

Published: 01/03/2017

Publisher's PDF, also known as Version of record

Cyswllt i'r cyhoeddiad / Link to publication

Dyfyniad o'r fersiwn a gyhoeddwyd / Citation for published version (APA):

Rockwell, C. A., Guariguata, M. R., Menton, M., Arroyo Quispe, E., Quaedvlieg, J., WarrenThomas, E., Fernandez Silva, H., Jurado Rojas, E. E., Hideki Kohagura Arrunategui, J. A., Meza Vega, L. A., Quenta Hancco, R., Revilla Vera, O., Valera Tito, J. F., Villarroel Panduro, B. T., \& Yucra Salas, J. J. (2017). Spatial distribution of Bertholletia excelsa in selectively logged forests of the Peruvian Amazon. Journal of Tropical Ecology, 33(2), 114-127.

https://doi.org/10.1017/S0266467416000614

Hawliau Cyffredinol / General rights

Copyright and moral rights for the publications made accessible in the public portal are retained by the authors and/or other copyright owners and it is a condition of accessing publications that users recognise and abide by the legal requirements associated with these rights.

- Users may download and print one copy of any publication from the public portal for the purpose of private study or research.

- You may not further distribute the material or use it for any profit-making activity or commercial gain

- You may freely distribute the URL identifying the publication in the public portal ?

Take down policy

If you believe that this document breaches copyright please contact us providing details, and we will remove access to the work immediately and investigate your claim. 


\title{
Spatial distribution of Bertholletia excelsa in selectively logged forests of the Peruvian Amazon
}

\author{
Cara A. Rockwell $1,2, *$, Manuel R. Guariguata ${ }^{1}$, Mary Menton ${ }^{1,3}$, Eriks Arroyo Quispe ${ }^{1,4}$, \\ Julia Quaedvlieg ${ }^{1}$, Eleanor Warren-Thomas ${ }^{1,5}$, Harol Fernandez Silva ${ }^{1,4}$, \\ Edwin Eduardo Jurado Rojas ${ }^{1,4}$, José Andrés Hideki Kohagura Arrunátegui ${ }^{1,4}$, \\ Luis Alberto Meza Vega ${ }^{1,4}$, Roger Quenta Hancco ${ }^{1,4}$, Olivia Revilla Vera ${ }^{1,4}$, \\ Jonatan Frank Valera Tito ${ }^{1,4}$, Betxy Tabita Villarroel Panduro $0^{1,4}$ and Juan José Yucra Salas ${ }^{1,4}$ \\ ${ }^{1}$ Center for International Forestry Research (CIFOR), Lima, Perú \\ 2 International Center for Tropical Botany, Department of Earth and Environment, Florida International University (FIU), Miami, FL, USA 33199 \\ ${ }^{3}$ Solutions \& Evidence for Environment \& Development (SEED) 106 Cowley Rd, Oxford OX4 1JE, UK \\ ${ }^{4}$ Universidad Nacional Amazónica de Madre de Dios (UNAMAD), Facultad de Ingeniería Forestal y Medio Ambiente, Puerto Maldonado, Madre de Dios, Perú \\ ${ }^{5}$ Centre for Ecology, Evolution and Conservation, School of Environmental Sciences, University of East Anglia, Norwich NR4 7TJ, UK \\ (Received 8 January 2016; revised 6 December 2016; accepted 7 December 2016; first published online 9 January 2017)
}

\begin{abstract}
To date, the spatial distribution pattern and density of Brazil nut trees in logged forest stands is unclear across the Amazon basin. We asked the following questions: (1) What are the densities and spatial distributions of Brazil nut juveniles $(10 \leq \mathrm{dbh}<40 \mathrm{~cm})$ and adults $(\geq 40 \mathrm{~cm} \mathrm{dbh})$ in three selectively logged Brazil nut concessions (1413 ha sampled) in Madre de Dios, Peru; (2) What is the spatial relationship between adults and juveniles ( $10 \leq \mathrm{dbh}$ $<30 \mathrm{~cm}$ ); and (3) What is the spatial relationship between juveniles $(10 \leq \mathrm{dbh}<30 \mathrm{~cm})$ and cut stumps $(\geq 10 \mathrm{y})$ ? Spatial analyses were conducted using statistics derived from Ripley's K function. Juveniles were aggregated in all three concessions. Results for adult populations rejected the null hypothesis of a random distribution among trees $\geq$ $40 \mathrm{~cm} \mathrm{dbh}$. We did not find an attraction between juveniles and cut-stump locations, nor between adults and juveniles. The strong peaks of aggregation for juveniles and adult Brazil nuts in this study occurred at long distances (300-900 $\mathrm{m})$, suggesting multiple tree canopy gaps as drivers of spatial distribution patterns, either via natural or anthropogenic sources. Our data contribute to a more thorough understanding of Brazil nut population structure in disturbed forests in south-western Amazonia.
\end{abstract}

Key Words: Brazil nut, multiple-use forest management, Ripley's K, smallholder, spatial patterns, timber extraction

\section{INTRODUCTION}

The Amazonian Brazil nut tree (Bertholletia excelsa H.B.K., Lecythidaceae) is gap-dependent (Myers et al. 2000, Ortiz 2002), favouring open forest areas for early growth and survival (Cotta et al. 2008, Kainer et al. 1998, Mori \& Prance 1990). Brazil nut's persistence in postdisturbance, successional stages has led some researchers to label it as a long-lived pioneer (Swaine \& Hall 1987, Zuidema 2003). Brazil nut populations are often described in terms of groves, due to a distinct clumped distribution pattern at the landscape scale (i.e. aggregates that span over thousands of hectares; Mori \& Prance 1990, Peres

* Corresponding author. Email: crockwel@fiu.edu
\& Baider 1997, Peres et al. 2003, Shepard \& Ramirez 2011, Thomas et al. 2014). Groves can also be defined at the local scale, complicating the determination of niche and dispersal drivers (John et al. 2007). The aggregated pattern of Brazil nut groves has been linked to a mix of biophysical and anthropogenic causes (Scoles \& Gribel 2012, Thomas et al. 2015), including (1) shortrange seed dispersal by scatterhoarding caviomorph rodents (Haugaasen \& Haugaasen 2010, Haugaasen et al. 2012, Peres \& Baider 1997); (2) early establishment in natural canopy gaps (Mori \& Prance 1990); (3) historical abandonment of swidden agricultural fields (Balée 1989, Scoles \& Gribel 2011); (4) accidental scattering of seeds along harvest trails (Ribeiro et al. 2014); and (5) formation and maintenance of groves by indigenous groups (Ribeiro et al. 2014). 
Anthropogenic disturbances are also thought to be responsible for high densities of juvenile Brazil nut trees in the Eastern Amazon (Scoles \& Gribel 2012, 2015). In Western Amazonia, recent studies have demonstrated enhanced early regeneration of Brazil nut in logging gaps and skid trails (Moll-Rocek et al. 2014, Soriano et al. 2012). It is unclear, however, if this positive association with logging gaps continues throughout later life stages. Even though a Brazil nut tree can survive as an intermediate-sized juvenile once the forest canopy closes, development is often hindered due to low light levels (Scoles \& Gribel 2012). Suppressed Brazil nut trees grow at rates a tenth of those in dominant and co-dominant crown positions (Staudhammer et al. 2013), increasing the probability of mortality (Swaine et al. 1987, Terborgh et al. 1997). A pronounced gap mosaic, characteristic of selectively logged forests, and where the canopy remains open for several years (Asner et al. 2004) may allow both increased recruitment and growth rates of Brazil nut trees. For example, growth responses to nearby logging gaps were overwhelmingly positive for several tropical tree species in a selectively logged forest in French Guiana (Herault et al. 2010a).

Despite the prevalence of Brazil nut-timber management systems (especially in the south-western Amazon region), most scientific work about Brazil nut ecology and population dynamics derives from unlogged forests (Kainer et al. 2014, Peres et al. 2003, Staudhammer et al. 2013, Wadt et al. 2005, Zuidema \& Boot 2002). To our knowledge, no published study has yet examined the density and spatial distribution pattern of Brazil nut adult $(\geq 40 \mathrm{~cm} \mathrm{dbh})$ and juvenile $(10 \leq \mathrm{dbh}<40 \mathrm{~cm})$ tree populations in selectively logged forests. In this study we assessed the spatial structure of Brazil nut populations in three selectively logged forests in Peruvian Amazonia. We hypothesized that densities of juvenile Brazil nut stems would be higher than juvenile density in unlogged forests relative to adult stems, due to the long history of timber exploitation along the Interoceánica Sur Highway (IOS), which connects Brazil with Peruvian ports. We also expected to find a positive spatial association between juvenile stems and cut stumps.

\section{METHODS}

\section{Study area}

Given the potential variability of Brazil nut tree distribution across the landscape, the study was conducted in three Brazil nut concessions (henceforth referred to as Alegria I (290 ha), Alegria II (547 ha), Alegria III (576 ha)) located 5-20 km apart in southeastern Peru, Tambopata Province, Department of Madre de Dios $\left(11^{\circ} 30^{\prime} 30^{\prime \prime}-12^{\circ} 10^{\prime} 0^{\prime \prime} \mathrm{S}, 69^{\circ} 56^{\prime} 0^{\prime \prime}-69^{\circ} 21^{\prime} 0^{\prime \prime} \mathrm{W}\right)$.
Surveys were conducted from September 2013 to July 2014 (Figures 1, 2). Sites were selected following a series of meetings (conducted in October 2012) with concessionaire associations in the settlement of Alegría. The selection of the three concessions for inclusion in the study was based primarily on concessionaire interest and site accessibility. The Brazil nut trees located in these concessions belong to a single Brazil nut metapopulation located along the IOS between Puerto Maldonado and Alerta (IIAP-CTAR 2001). In all three concessions, Brazil nut harvesting was taking place on an informal basis prior to the arrival of the current concessionaires (1978, 1979 and 1999, respectively). At present, all three concessionaires claim to harvest up to $90 \%$ of the annual Brazil nut annual production, leaving approximately $10 \%$ for regeneration and forage for important game taxa such as agoutis (Dasyprocta spp.), the spotted paca (Cuniculus paca) and various primate species.

Mean annual rainfall in the region ranges from 2500 to $3500 \mathrm{~mm}$, with a pronounced rainy season from December to March (Chávez et al. 2012, Tobler et al. 2009). Mean annual temperature is $24^{\circ} \mathrm{C}$, but it fluctuates within an extreme range for the neotropics $\left(10-38^{\circ} \mathrm{C}\right.$; Tobler et al. 2009). The landscape is defined by acidic, well-drained soils of moderate to low fertility and gently undulating to flat topography. Madre de Dios is dominated by a mix of humid tropical forests in both elevated terra firme and low-lying floodplain sites (Asner et al. 2013). The department claims $\sim 90 \%$ forest coverage, which is high in comparison with other regions of the Amazon Basin (Asner et al. 2009), but forest cover is expected to decline in the future, following the paving of the IOS, which was completed in 2010 (Perz et al. 2013). Prior to the paving, the highway had been in existence for several decades, but was often impassable during the rainy season.

Low-intensity timber extraction was prevalent in Brazil nut-rich forests several decades before the concession system was established and logging was formalized by a government decree in 2004 (Cossío-Solano et al. 2011). Over the last decade, officially sanctioned timber extraction intensities have ranged from 1-3 trees $\mathrm{ha}^{-1}$ ( 5-10 $\mathrm{m}^{3} \mathrm{ha}^{-1}$; Cossío-Solano et al. 2011), but they can exceed this amount, especially when informal practices are the norm (Rockwell et al. 2015). All three concessionaires associated with our study confirmed the long-term presence of logging in their concessions through first-hand knowledge, the presence of stumps predating their arrival, or communication with previous concessionaires. Logging activity dates in all three cases to at least the late 1960s-early 1970s, when hardwood species such as Swietenia macrophylla and Cedrela odorata (both Meliaceae) were the preferred commercial taxa. Species currently favoured for timber harvesting (given the historic high grading of hardwood 


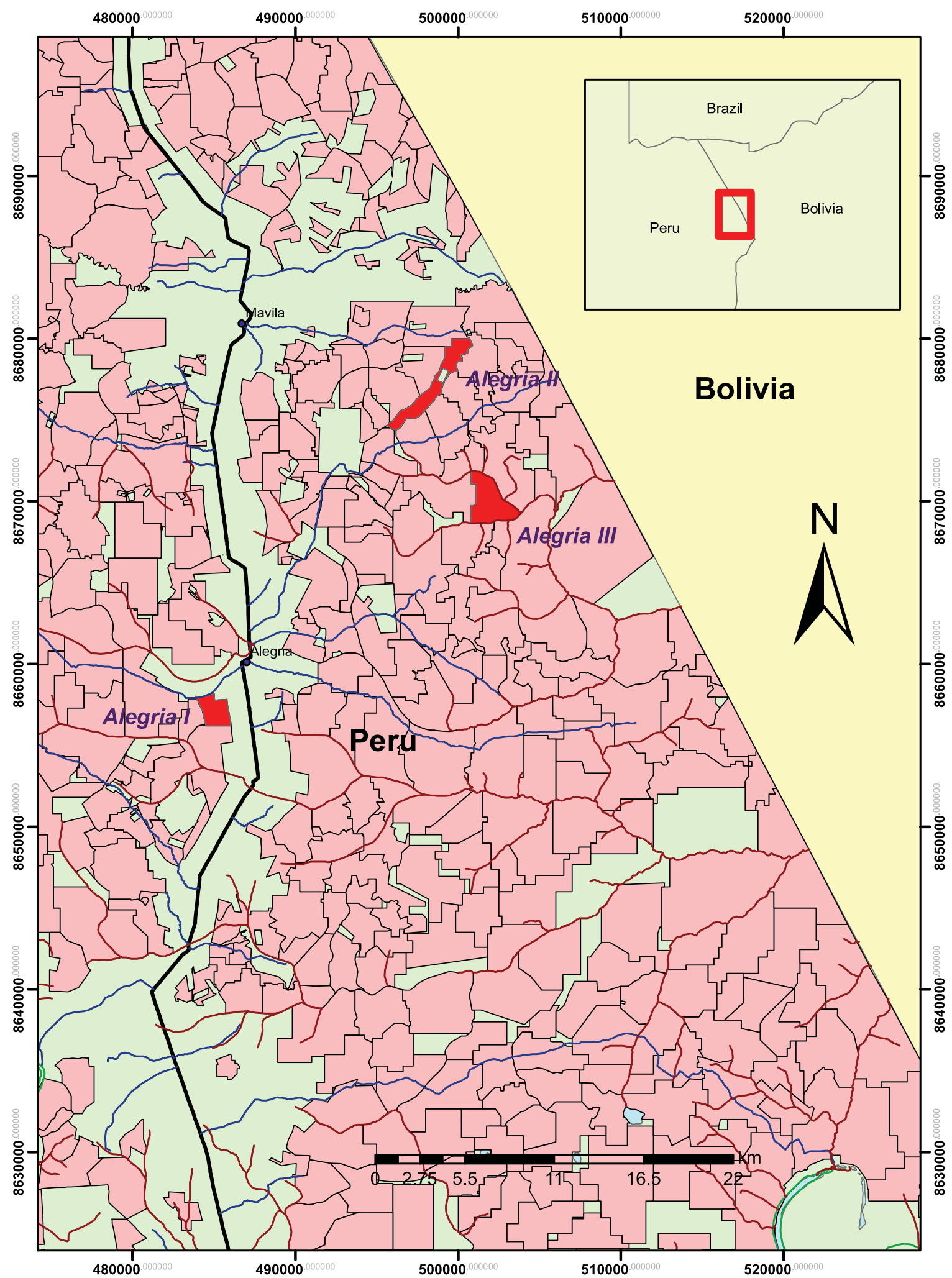

Figure 1. Location of study sites (Alegria I, Alegria II, Alegria III) in Madre de Dios, Peru. The pale pink shade refers to all Brazil nut concessions not associated with the study. The red shade refers to all participating Brazil nut concessions. The dark line running north-south refers to the Interoceánica Sur Highway. 

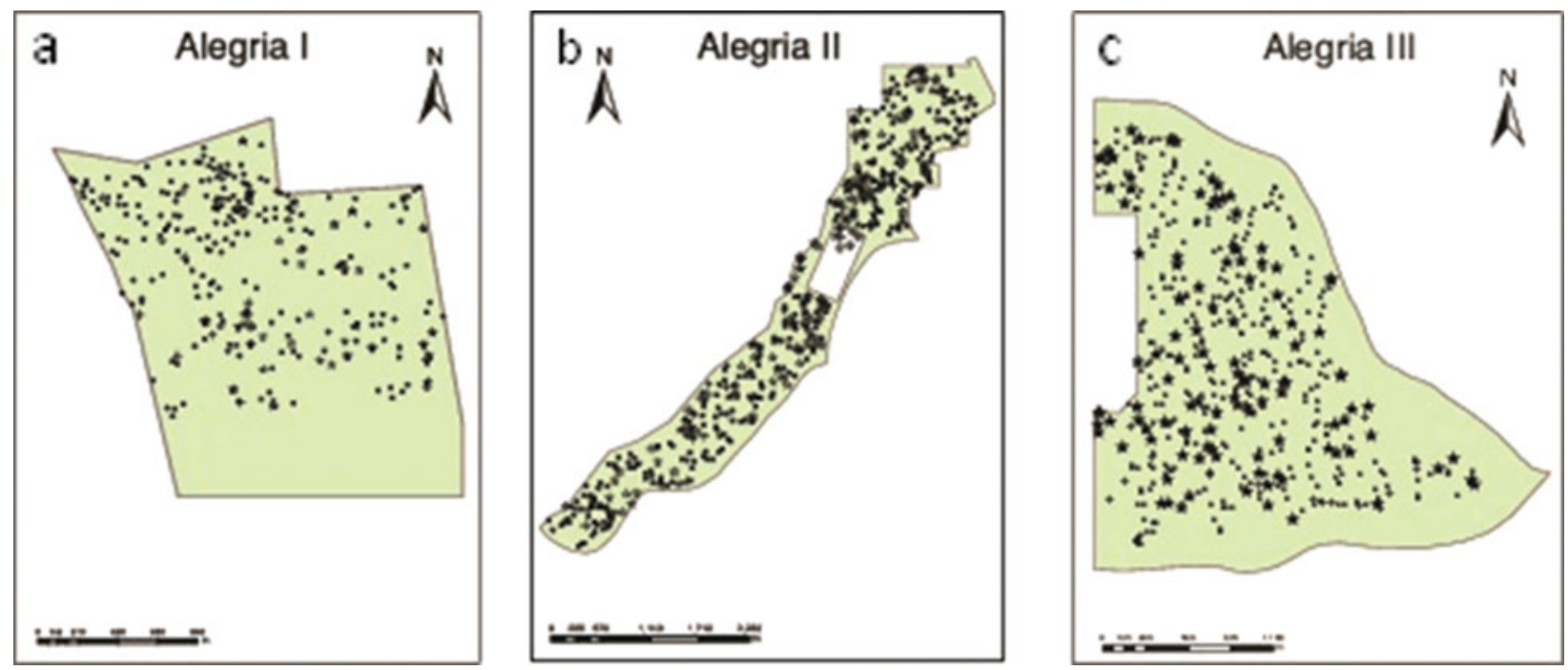

Figure 2. Maps of the study sites, Alegria I (a, 290.6 ha), Alegria II (b, 547.3 ha), and Alegria III (c, 576.3 ha), in Madre de Dios, Peru. The white stars refer to juvenile Brazil nut trees $(10 \leq \mathrm{dbh}<40 \mathrm{~cm})$. The solid black circles refer to the adult Brazil nut trees $(\mathrm{dbh} \geq 40 \mathrm{~cm})$. The black crosses refer to cut stumps ( $\geq 10 \mathrm{y}$ ). The white rectangle refers to an abandoned agricultural field (Alegria II).

species) include Cedrelinga catenaeformis (Fabaceae), Matisia spp. (Malvaceae), Ceiba pentandra (Malvaceae) and Couratari spp. (Lecythidaceae), the latter three all considered softwood species. Although timber removal generally occurs during the dry season, at least two of the concessions in this study were recently subjected to logging at the height of the rainy season. Two of the three concessionaires, however, stated that their logging activities tend to be infrequent.

\section{Field measurements}

An exhaustive (100\%) tree inventory method was employed in the three concessions from September 2013 to July 2014. Surveys to locate juvenile Brazil nut stems were conducted across linear strips $40 \mathrm{~m}$ in width, running north-south within the concession borders. Brazil nut tree juveniles were located and georeferenced with a Garmin ${ }^{\circledR}$ GPSMap 62 handheld unit (precision 1-10 m). Dbh and physical characteristics such as visible damage (e.g. scraped bark, missing branches) and liana infestation, were recorded for each individual. Concessionaires accompanied field teams to verify locations of planted Brazil nut trees so as not to confuse them with natural regeneration; these were excluded from the analysis. Most planted stems were smaller than our size class of interest (i.e. $<10 \mathrm{~cm} \mathrm{dbh}$ ). Locations of all reproductive Brazil nut trees $(\geq 40 \mathrm{~cm} \mathrm{dbh})$ in each concession were also georeferenced with a Garmin ${ }^{\circledR}$ GPSMap 62 handheld unit (Figure 2).
Prior to the selection of the three concessions, we had no information about the intensity nor the spatial distribution of selective logging across these sites. Given the opportunistic nature of logging activities in Madre de Dios, timber has historically been harvested without regard to a regular cutting cycle. Historical cut stumps were inventoried in an exhaustive manner simultaneously with the juvenile Brazil nut tree survey. The ages of the cut stumps were estimated by the field team and confirmed with the concessionaires. To characterize the logging mosaic in each concession and to assess the relationship between cut-stump location on Brazil nut juvenile tree distribution and density, distance to nearest logging gap or cut stump was measured for each juvenile tree. Cut stumps younger than $10 \mathrm{y}$ were excluded from the analysis, as they are unlikely to have had an influence on the regeneration/recruitment of the juvenile stems due to a decrease in passage time (i.e. number of years spent in one size class) as the stems reach a larger size class (Brienen \& Zuidema 2006). Brazil nut tree diameter growth is highly variable, so estimating the ages of Brazil nut stems on site was untenable. For example, Schöngart et al. (2015) found that Brazil nut trees $(10 \leq \mathrm{dbh} \leq 40 \mathrm{~cm})$ from two sites in Central Amazonia ranged in age from 18-34 y. The oldest cut stumps encountered during the initial surveys in our study were $\sim 30-40$ y old. As such, we know that there is a strong likelihood that the older cut stumps relate to logging events contemporaneous to the germination date of some of the juvenile stems included in this study. In light of the variable stem growth rates of Brazil nut, younger cut stumps $(10 \leq$ and $<30 \mathrm{y})$ were also included in the analysis. Resulting logging gaps from 
this period could have feasibly favoured both germination and recruitment rates. All distance measurements were calculated using geo-referenced locations in ArcMap 10.1 (ESRI, Redlands, CA).

\section{Analysis}

Ecological point patterns are often characterized by a combination of spatial relationships, thus limiting the use of certain spatial analyses that employ only mean of distances (e.g. nearest-neighbour methods; Haase 1995). In contrast, the spatial point pattern analysis developed by Ripley (1977) uses all point-to-point distances for two-dimensional spatial data, demonstrating how spatial clustering, or dispersion, changes within the area specified. Specifically, Ripley's K function calculates the expected number of neighbours in a circle of a given radius $d$ centred on an arbitrary point in the pattern. The circle uses the given radius as a starting point, eventually encompassing the entire study site (i.e. the whole concession).

In order to describe the spatial patterns of both juvenile and adult tree populations, we used a univariate spatial pattern analysis based on a transformation of the Ripley's K (d) index (a linearized form of Ripley's K function; Ripley 1977) using the ads package in R 3.1.1 (http://CRAN.R-project.org/package=ads).

$$
L(d)=\sqrt{ }\left(\frac{K(d)}{\pi}\right)-d
$$

Under the null hypothesis of complete spatial randomness, $L(d)$ is 0 , or a homogeneous Poisson point process (Marcon et al. 2013), against which our observed set of points was tested. We estimated a confidence interval of $99 \%$ using the Monte Carlo method. The null hypothesis (i.e. random distribution) was simulated by computing 1000 Poisson distributions (Goreaud \& Pélissier 1999). For each particular distance $(d)$, the observed $L(d)$ value that differed from the expected $L(d)$ by the greatest amount is the confidence interval. If the observed $L(d)$ is larger than the expected $L(d)$ value at a particular distance, the pattern can be characterized as clustered; if it is smaller than the expected $L(d)$, the pattern is regular. To account for the irregular shapes of one of the concessions (Alegria II), we employed an edge-effect correction that supported the complex triangle assembly associated with our data set (Goreaud \& Pélissier 1999, Ripley 1977, Traissac \& Pascal 2014). The use of triangles in the analysis allows the removal of blank zones that would otherwise be used by the Ripley's function to calculate the spatial structure of the species in question.

To understand the spatial relationship between juvenile and adult populations, and between the juveniles and cut stumps, we employed the linearized intertype $\mathrm{L}_{12}$ function
(Goreaud \& Pélissier 2003, Traissac \& Pascal 2014):

$$
L_{12}(d)=\sqrt{\frac{K_{12}(d)}{\pi}}-d
$$

where $L_{12}(d)$ is 0 under the null hypothesis of independence between juveniles and adults and juveniles and cut stumps. Under the toroidal shift null model, a positive value of $L_{12}(d)$ indicates attraction between the two populations and a negative value indicates repulsion at a given distance (d; Traissac \& Pascal 2014). In this particular case, the positions of the points of one class remain unchanged while the points of the other class are shifted by the same random vector (Ledo et al. 2011). Accordingly, a confidence interval of 99\% was developed from 1000 random toroidal shifts for each analysis (Goreaud \& Pélissier 2003, Traissac \& Pascal 2014). When analysing the spatial patterns between juveniles and reproductive adults, we reduced the sample size of the juveniles to include only those individuals between $10 \leq \mathrm{dbh}<30 \mathrm{~cm}$ in order to avoid the assumption that smaller juveniles are the progeny of larger juvenile stems. Likewise, we limited the analysis of correlation between cut stumps and juvenile trees to Brazil nut stems between $10 \leq \mathrm{dbh}<30 \mathrm{~cm}$, given the possibility that larger juvenile individuals $(30 \leq \mathrm{dbh}<40 \mathrm{~cm}$ ) pre-date our oldest cut stumps ( $40 \mathrm{y})$.

\section{RESULTS}

\section{Descriptive statistics}

Total number of cut stumps $\geq 10$ y old, per concession, were 11 (Alegria I), 42 (Alegria II) and 18 (Alegria III; Figure 2). Two hundred and seventy-six Brazil nut trees ( $\geq 40 \mathrm{~cm} \mathrm{dbh}$ ) were found in Alegria I, 345 in Alegria II and 336 in Alegria III (Table 1, Figure 2). The location of adult trees in each concession was used to calculate local density (trees ha ${ }^{-1}$; Table 1). The adult density in Alegria III was the lowest of all three sites $\left(0.58\right.$ trees ha $\left.^{-1}\right)$, while Alegria I contained the highest density $\left(0.95\right.$ trees ha $\left.{ }^{-1}\right)$.

Thirty-six juvenile Brazil nut trees $(10 \leq \mathrm{dbh}<40 \mathrm{~cm})$ were found in Alegria I, 101 in Alegria II and 59 in Alegria III (Table 1, Figure 2). The location of juvenile trees in each concession was used to calculate local density (Table 1). The juvenile density in Alegria III was the lowest of all three sites $\left(0.10\right.$ trees ha $\left.{ }^{-1}\right)$, while Alegria II contained the highest density $\left(0.19\right.$ trees $\left.\mathrm{ha}^{-1}\right)$, as well as the highest percentage of juveniles (Table 1).

\section{Spatial patterns}

Aggregated distribution patterns were found for the adult tree size class in all three concessions (Figure 3). The 
Table 1. Descriptive statistics of population structure of Bertholletia excelsa in three Brazil nut concessions in Madre de Dios, Peru.

\begin{tabular}{llccc}
\hline Parameter & \multicolumn{1}{c}{ dbh size class $(\mathrm{cm})$} & Alegria I & Alegria II & Alegria III \\
\hline Area $($ ha $)$ & & 290.6 & 547.3 & 576.3 \\
Total number trees & $\geq 10$ & 312 & 446 & 395 \\
Total number trees & $\geq 40$ & 276 & 345 & 336 \\
Total number trees & $10 \leq$ and $<40$ & 36 & 101 & 59 \\
Tree density $\left(\right.$ tree $\left.^{-1}\right)$ & $\geq 10$ & 1.07 & 0.82 & 0.69 \\
Tree density $\left(\right.$ tree $\left.^{-1}\right)$ & $\geq 40$ & 0.95 & 0.63 & 0.58 \\
Tree density $\left(\right.$ tree ha $\left.^{-1}\right)$ & $10 \leq$ and $<40$ & 0.12 & 0.19 & 0.10 \\
Avg. distance $(\mathrm{m})$ between trees & $\geq 10$ & 44.7 & 53.6 & 55.8 \\
Avg. distance $(\mathrm{m})$ between trees & $\geq 40$ & 46.6 & 55.8 & 57.4 \\
Avg. distance $(\mathrm{m})$ between trees & $10 \leq$ and $<40$ & 110.7 & 95.6 & 66.2 \\
Avg. distance $(\mathrm{m})$ between trees & $(10 \leq$ and $<40)$ and $(\geq 40)$ & 66.5 & 108.9 & 68.1 \\
Juvenile stems $($ per adult) & & 0.13 & 0.29 & 0.18 \\
\hline
\end{tabular}

strongest peaks of aggregation were found in Alegria I $(\sim 700 \mathrm{~m})$ and Alegria II $(300 \mathrm{~m})$. At all three sites, spatial aggregation patterns were observed amongst juvenile stems (Figure 4), but with significant peaks of clustering noted solely in Alegria II at 500 m. In Alegria III, juveniles were randomly distributed up to $\sim 600 \mathrm{~m}$, at which point the pattern became spatially aggregated, with one peak of aggregation noted at $800 \mathrm{~m}$. Aggregation patterns peaked at $900 \mathrm{~m}$ in Alegria I.

Overall, our results demonstrated a lack of juveniles near mature trees. Average distances between nearest reproductive neighbour and juvenile stems were higher in Alegria II than Alegria I (66.5 m) or Alegria III (68 m), with a median distance of $108.9 \mathrm{~m}$ (Table 1). We did not find significant attraction or dispersion between juvenile and adult Brazil nut trees at any given radial distance using the intertype point pattern analysis (Figure 5). No significant attraction or repulsion patterns were discernible between cut stumps $\geq 10 \mathrm{y}$ old and juvenile trees (Figure 6).

\section{DISCUSSION}

Much of the literature on Brazil nut tree ecology has confirmed the existence of local and landscape scale groves (Mori \& Prance 1990, Peres \& Baider 1997, Salomão 1991). Despite relatively low densities of reproductive adults, results from our sites appear to corroborate those findings - spatial aggregations at the local scale $\left(<6 \mathrm{~km}^{2}\right)$ were found in all three concessions for this size class (Figure 3). We submit that the scattered gap mosaic conditions of South-Western Amazon forests likely favour grove formation, even in the absence of anthropogenic disturbance. For example, Asner et al. (2013) determined that forests in Madre de Dios are subject to large gap-forming processes due to strong winds (or blowdowns (30-2000 ha); Nelson et al. 1994) as well as smaller-scale canopy damage resulting from mass loading of bamboo (Guadua sarcocarpa and G. weberbaueri) culms (Griscom \& Ashton 2006). Although a direct link has yet to be made between Brazil nut groves and these natural canopy disturbance events, such phenomena would surely introduce elevated light levels to the forest, the most limiting resource for Brazil nut tree growth (Staudhammer et al. 2013).

We predicted that juvenile density in these forests would be high, given our knowledge of the positive influence of other anthropogenic disturbances on Brazil nut densities in unlogged forests (Scoles \& Gribel 2011). Juvenile densities in our three concessions, however, are low when compared with unlogged sites in the Amazon. Indeed, in the cases of Alegria I and Alegria III, juveniles comprise a small proportion of the entire Brazil nut tree population (12.5\% and $14.9 \%$ respectively) when compared with other Amazonian studies (Scoles \& Gribel 2011). In spite of enhanced light levels, it is possible that the risk of juvenile mortality is increased in logged sites (Jansen \& Zuidema 2001); damage to pre-reproductive Brazil nut stems as a result of timber harvesting has been cited as a threat for Brazil nut tree populations (Guariguata et al. 2009). It can also be argued that since historical logging activities in Madre de Dios were typically characterized by low logging intensities (and indeed, are still today; Cossío-Solano et al. 2011, Rockwell et al. 2015), the size of the resulting gaps may not have been sufficient in size to enhance Brazil nut regeneration and recruitment over the long term (Fredericksen \& Putz 2003).

But could low juvenile density also indicate a regeneration failure linked to seed overharvesting and independent of logging activities? Other researchers have noted that long-term NTFP harvests can lead to population decline (Herrero-Jáuregui et al. 2012, Ticktin 2004). In Madre de Dios, the increase in demand for Brazil nut in both the national and international markets and the recent IOS road paving has intensified harvesting pressure on contemporary Brazil nut gatherers. Thus, we suspect that current harvest intensities $(\sim 90 \%$ of total 
(a) Alegria I

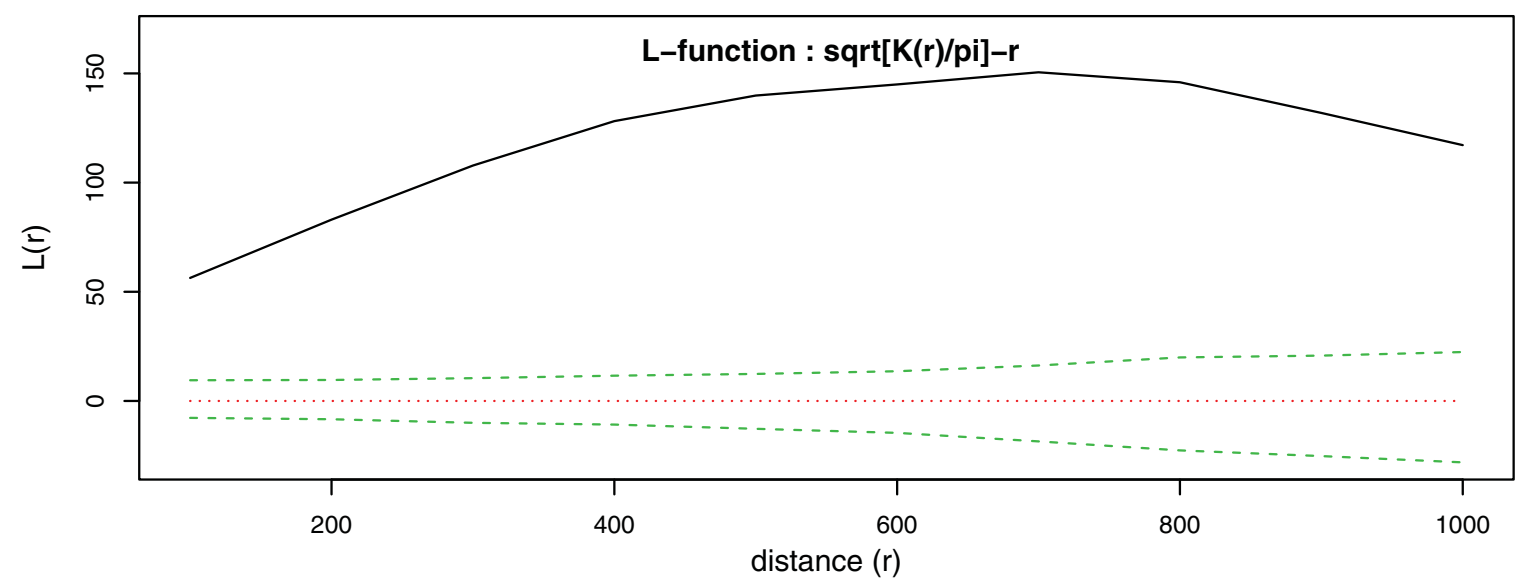

(b) Alegria II

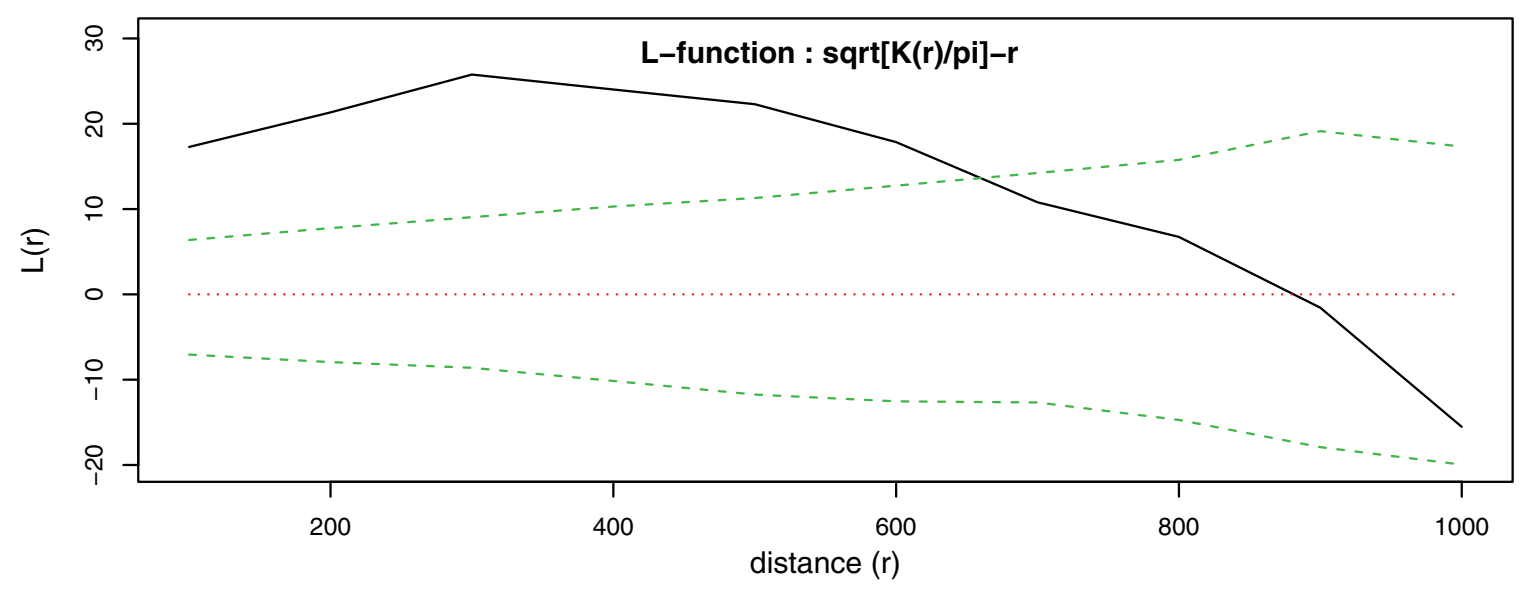

(c) Alegria III

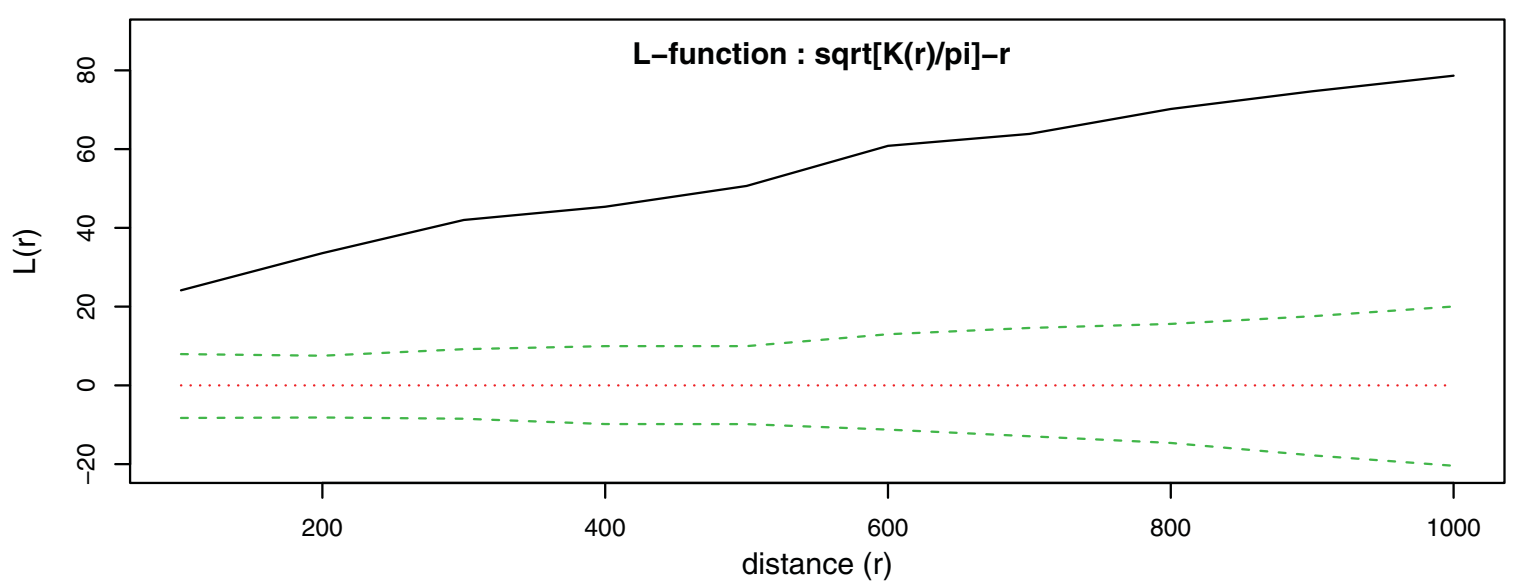

Figure 3. Spatial pattern analyses of adult $(\mathrm{dbh} \geq 40 \mathrm{~cm})$ Bertholletia excelsa trees in three sites in Madre de Dios, Peru. The solid black line refers to the $L(d)$ index (observed spatial pattern). The dotted violet line refers to the random (expected) spatial pattern. The dotted green line refers to the confidence interval. The sites include Alegria I (a), with a local density of 0.95 stems ha $^{-1}$; Alegria II (b), with local density of 0.63 stems ha ${ }^{-1}$; and Alegria III (c), with local density of 0.58 stems ha $^{-1}$. 
(a) Alegria I

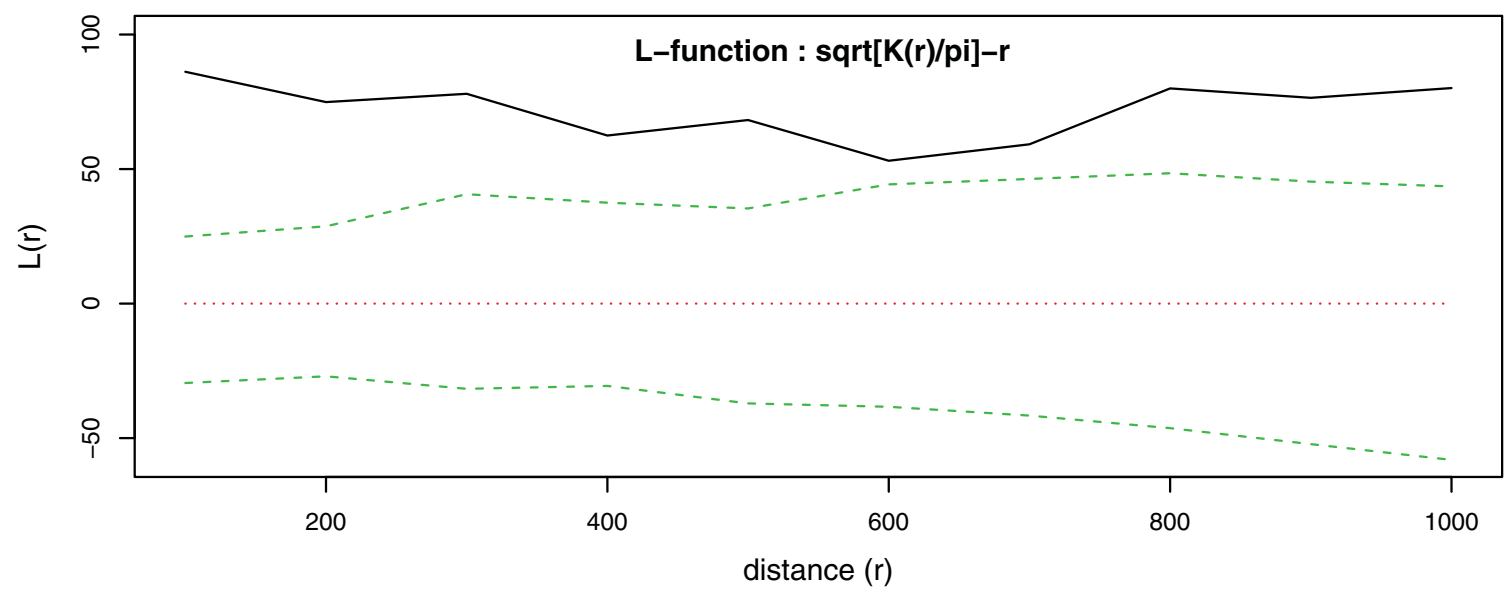

(b) Alegria II

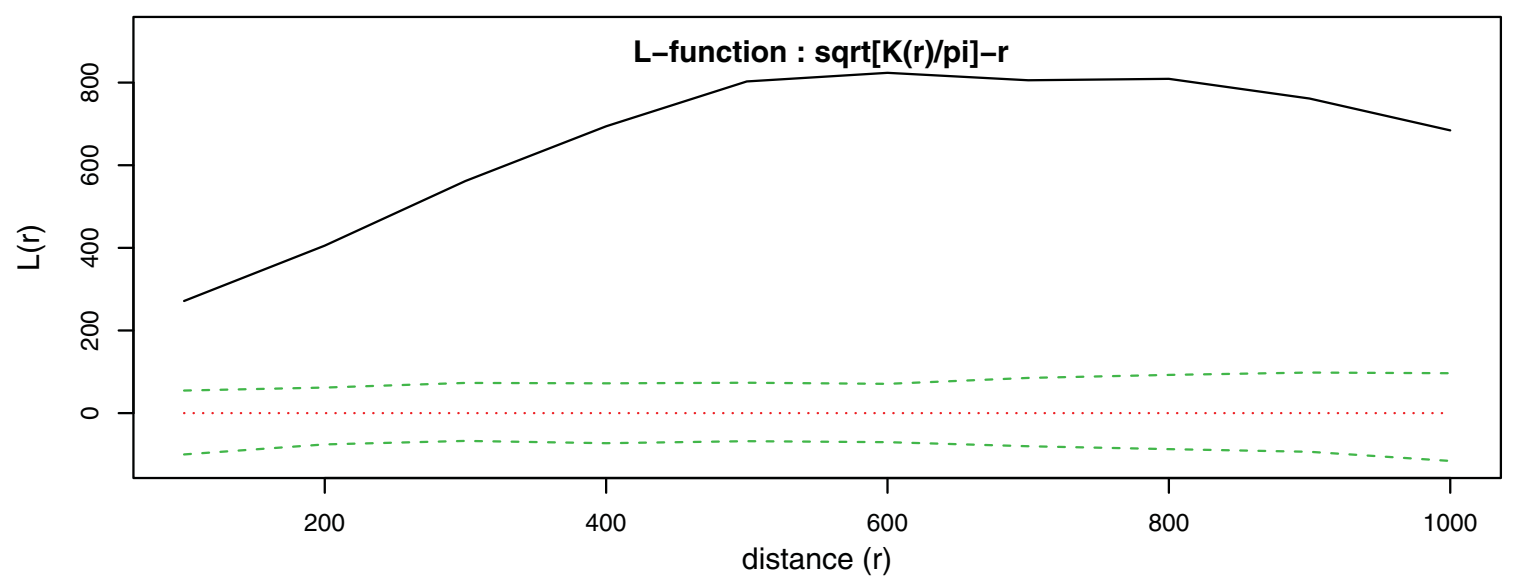

(c) Alegria III

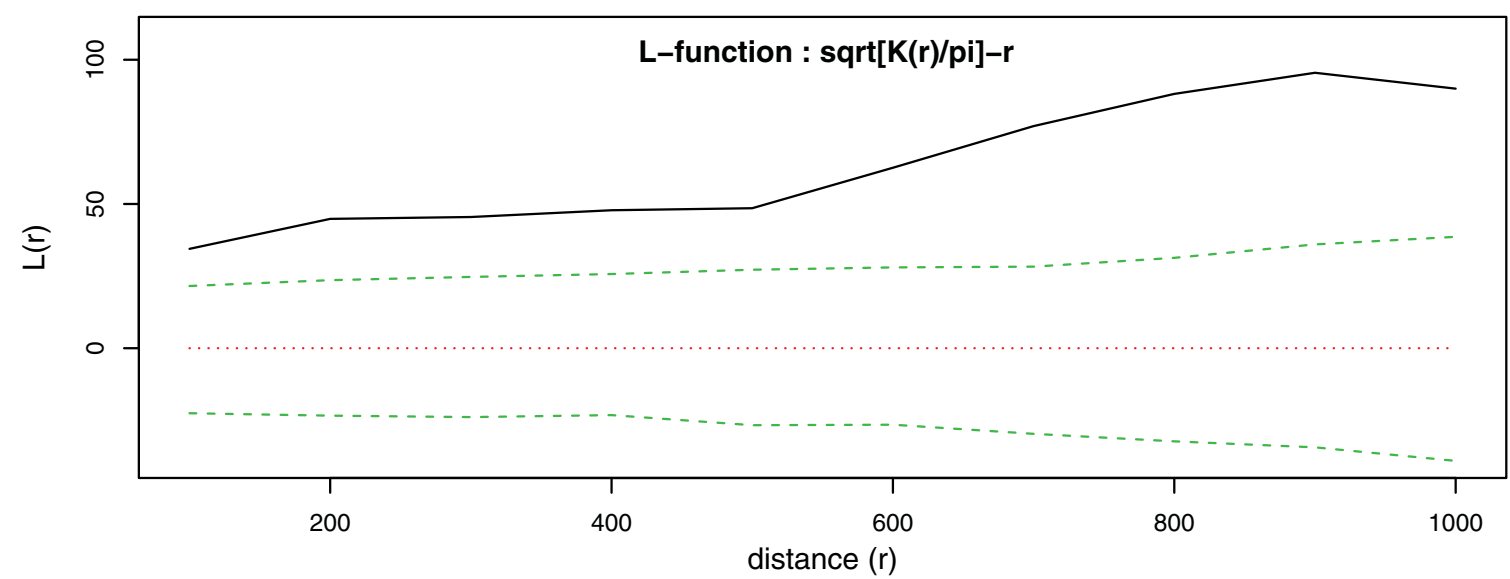

Figure 4. Spatial pattern analyses of juvenile $(10 \leq \mathrm{dbh}<40 \mathrm{~cm})$ Bertholletia excelsa trees in three sites in Madre de Dios, Peru. The solid black line refers to the $L(d)$ index (observed spatial pattern). The dotted violet line refers to the random (expected) spatial pattern. The dotted green line refers to the confidence interval. The sites include Alegria I (a), with local density of 0.12 stems ha $^{-1}$; Alegria II (b), with local density of 0.19 stems ha ${ }^{-1}$;

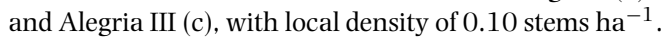


(a) Alegria I

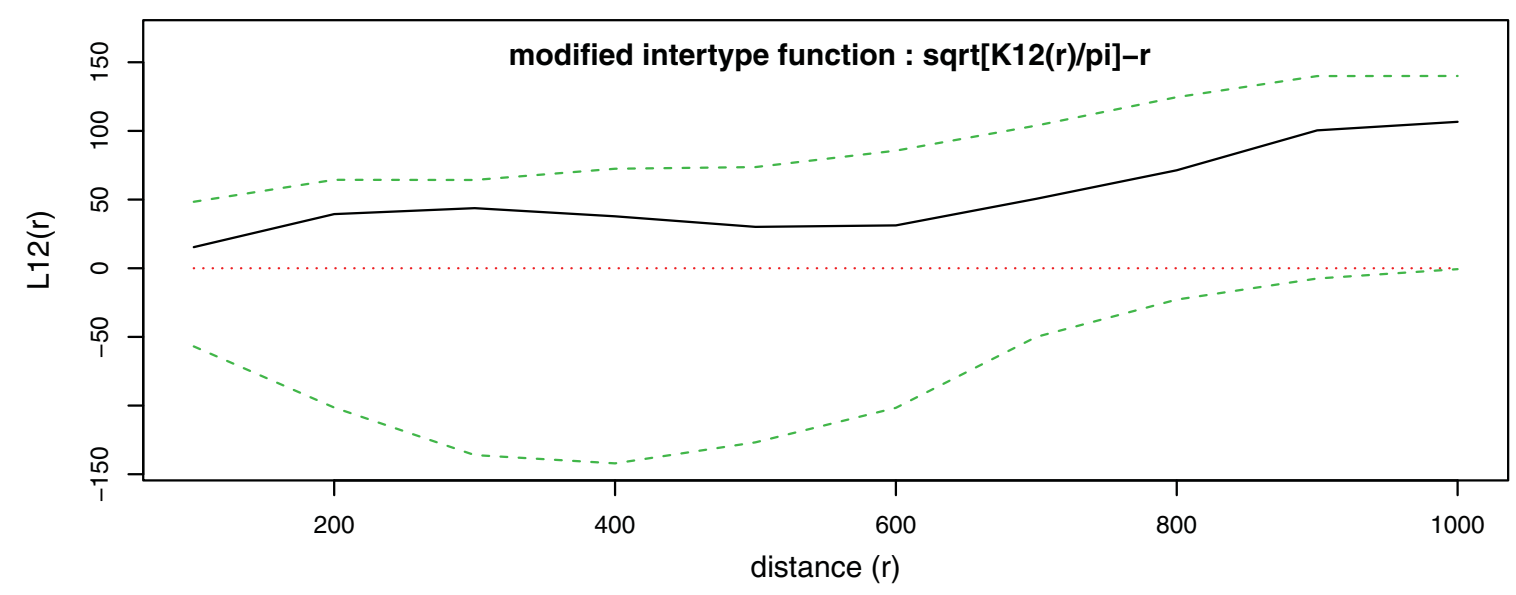

(b) Alegria II

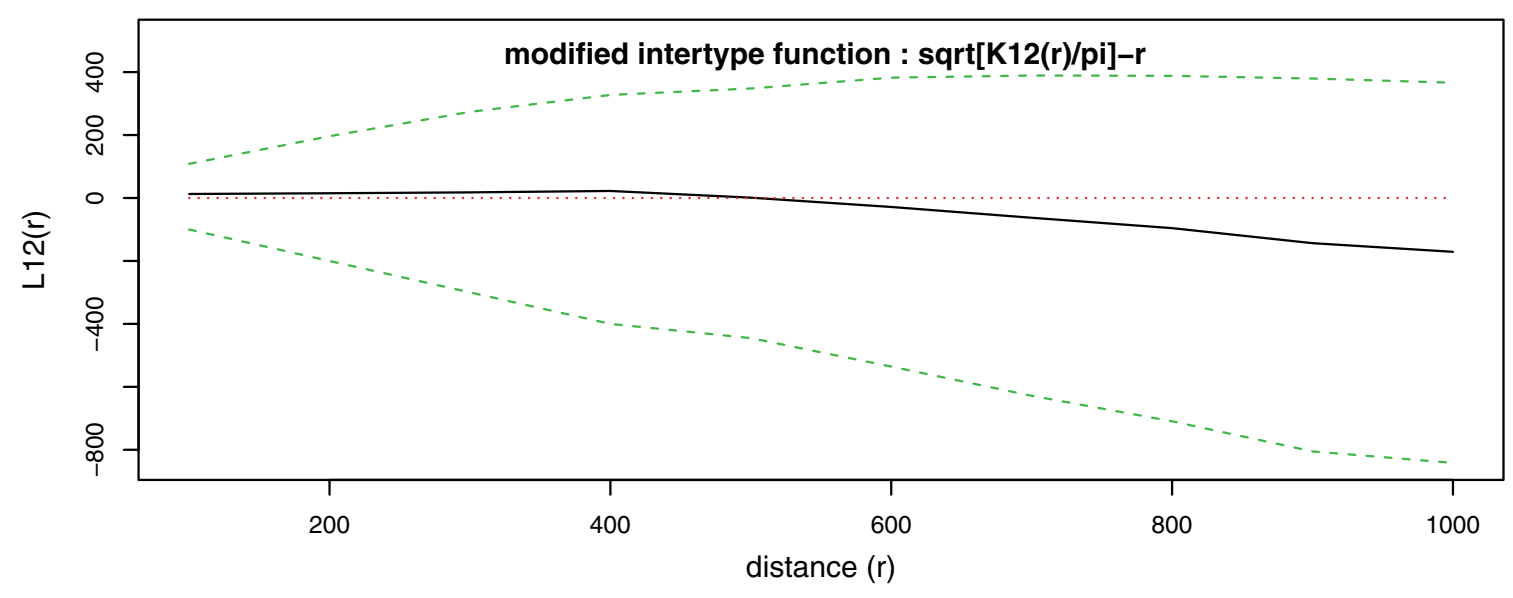

(c) Alegria III

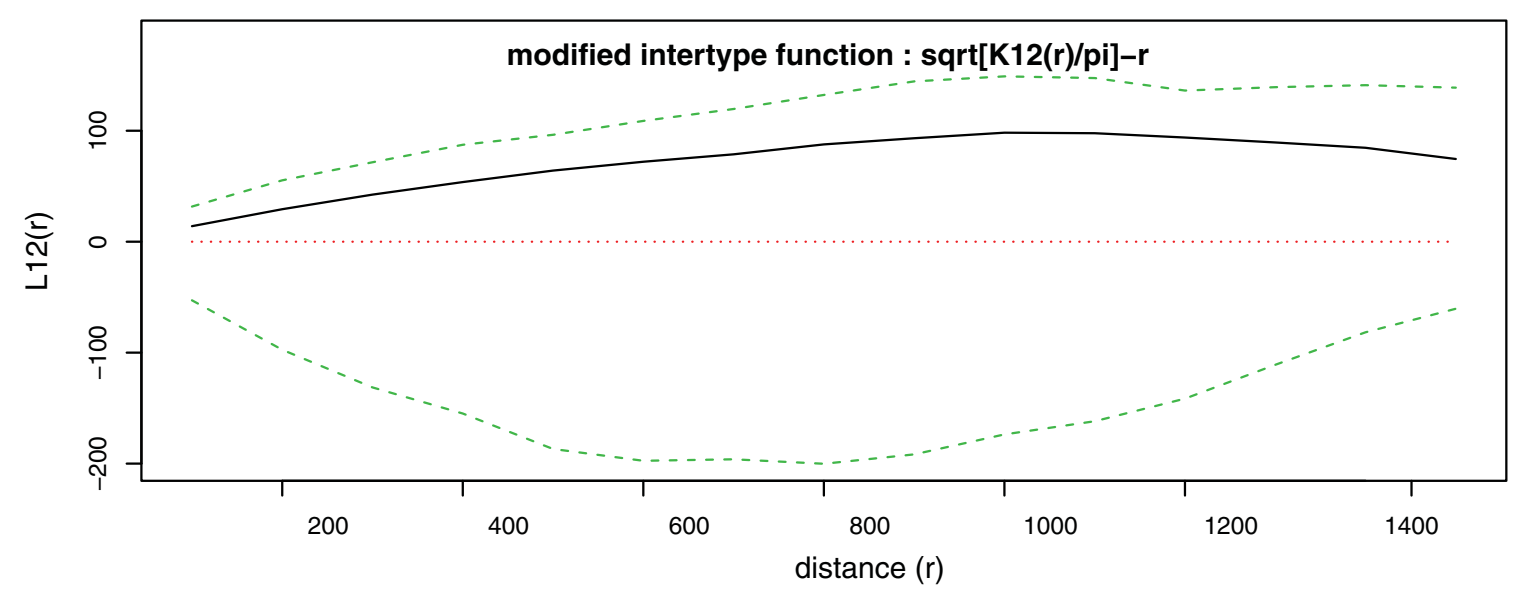

Figure 5. Spatial relation between juvenile $(10 \leq \mathrm{dbh} \leq 30 \mathrm{~cm})$ and adult $(\mathrm{dbh} \geq 40 \mathrm{~cm})$ Bertholletia excela trees in three sites in Madre de Dios, Peru. The solid black line refers to the $L(d)$ index (observed spatial pattern). The dotted violet line refers to the random (expected) spatial pattern. The dotted green line refers to the confidence interval. The sites include Alegria I (a); Alegria II (b); and Alegria III (c). 


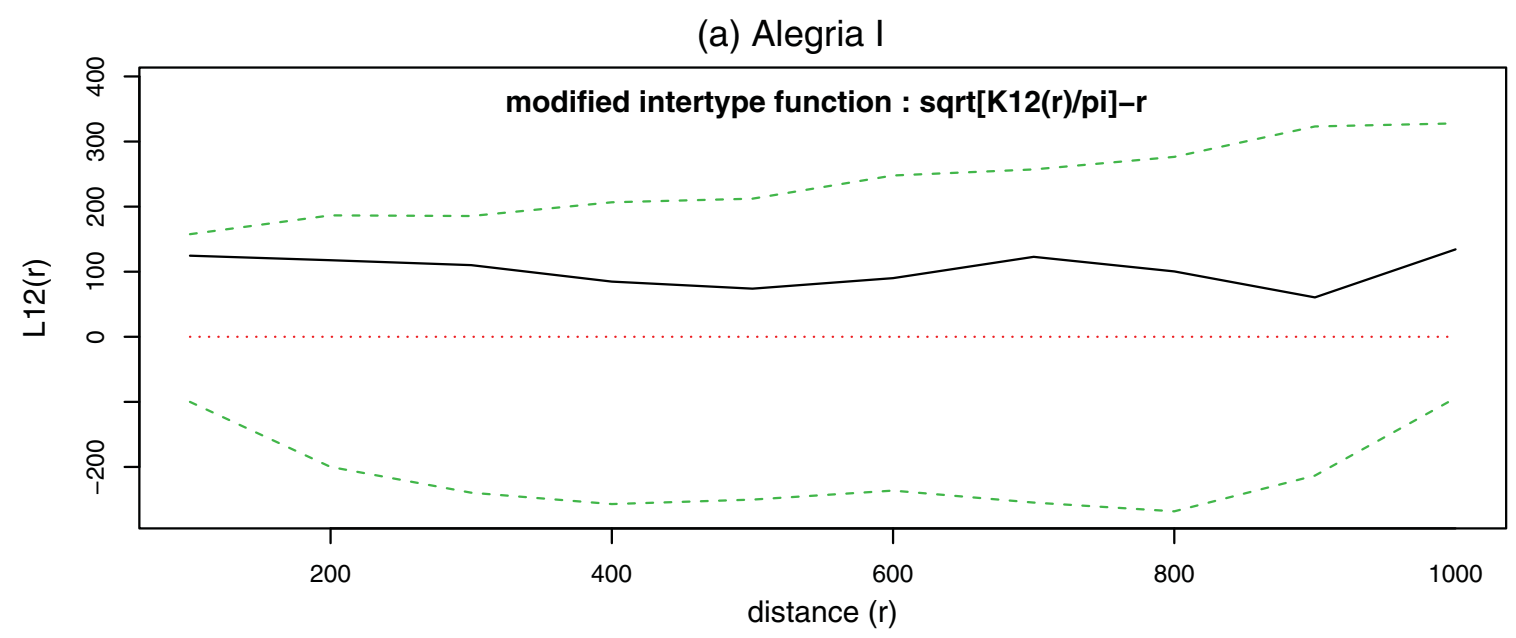

(b) Alegria II

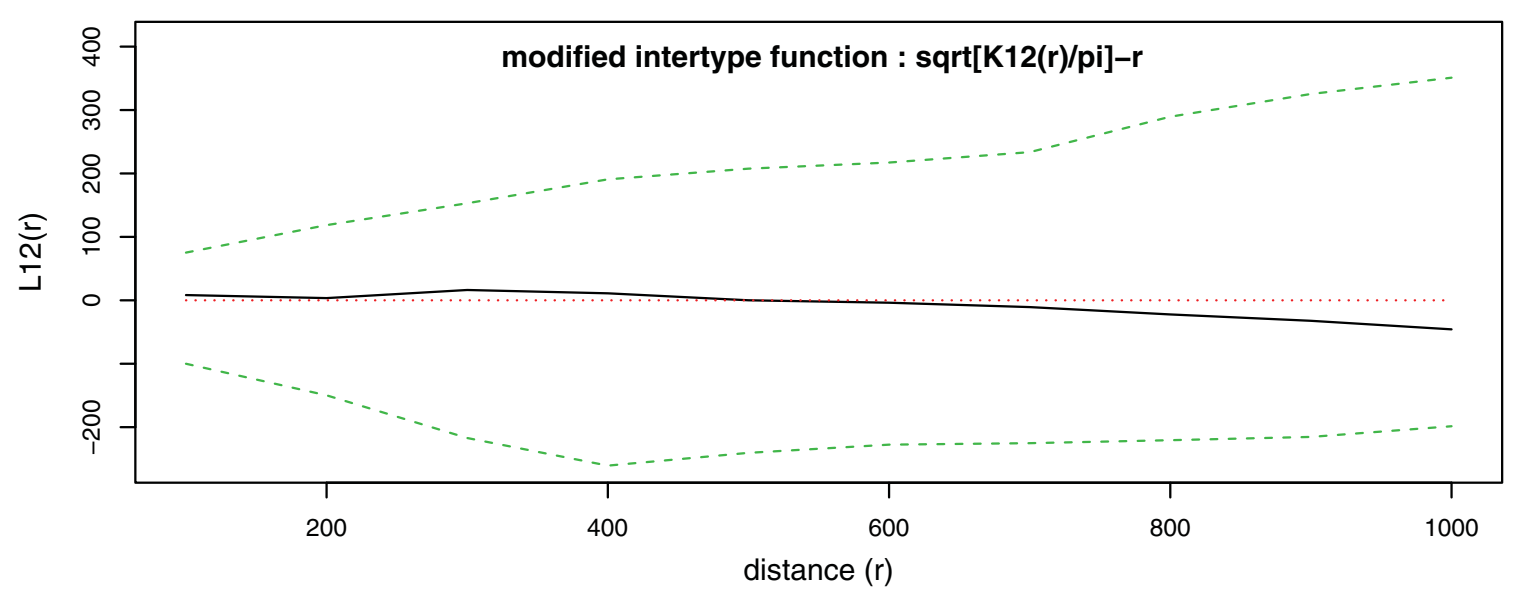

(c) Alegria III

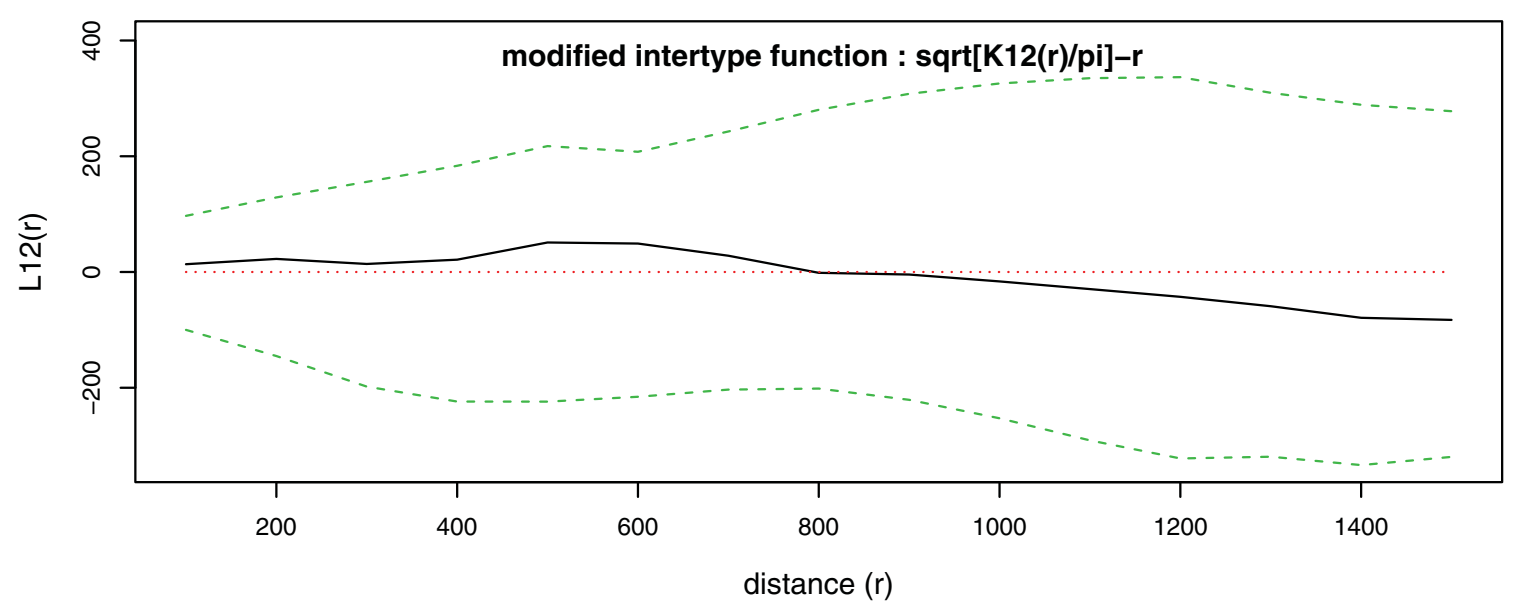

Figure 6. Spatial relation between juvenile $(10 \leq \mathrm{dbh} \leq 40 \mathrm{~cm})$ Bertholletia excela trees and location of cut stumps ( $\geq 10 \mathrm{y})$ in three sites in Madre de Dios, Peru. The solid black line refers to the $L(d)$ index(observed spatial pattern). The dotted violet line refers to the random (expected) spatial pattern. The dotted green line refers to the confidence interval. The sites include Alegria I (a); Alegria II (b); and Alegria III (c). 
seed crop, according to concessionaires) are likely higher than in previous decades (Cardó et al. 2002), leading us to conclude that the low juvenile stem density in our sites is not completely atypical and probably not the result of historical harvesting practices. Indeed, the predominance of large, centenarian individuals and scarcity of juveniles are common features of Brazil nut stands (Nepstad et al. 1992, Peres \& Baider 1997, Scoles \& Gribel 2012).

Clumping patterns were detected in all three sites for the juvenile size class (Figure 4), but juvenile groves were not related to location of cut stumps. Our knowledge of historical logging is based on location of old cut stumps and interviews with the concessionaires. It is possible that we did not find the locations of all old cut stumps; stump decomposition can take place within a relatively short period of time, especially in sites characterized by a prolonged rainy season (Delaney et al. 1998). Nonetheless, given historical logging practices, most of the cut stumps found in the concessions are remnants of stems characterized by high wood density and large diameter, characteristics determined by Herault et al. (2010b) to be strong predictors for wood decay. We know from other tropical studies, though, that tree distribution patterns are influenced by many different environmental factors, challenging the process of identifying specific drivers (Traissac \& Pascal 2014). For example, our study was not able to account for the role of natural gaps which generally provide favourable conditions for seedling establishment and growth of Brazil nut. If recruitment is enhanced by large-scale canopy openings (e.g. blowdowns), the clustering effect might be seen at larger (and variable) distances, similar to the patterns observed in all three concessions in this study for the juvenile size class.

The clumping patterns detected in the juvenile populations can also be explained by other factors: aggregation patterns of juvenile and adult trees can be influenced by frugivore activity (Bleher \& BöhningGaese 2001). In the case of Brazil nut, agoutis normally scatterhoard fruits at limited distances of 5-60 m (Haugassen et al. 2012, Peres \& Baider 1997). Under such circumstances, one would anticipate that cohorts of half-siblings dispersed by small mammals would be centred at short distances from mother trees (Nathan \& Muller-Landau 2000). The lack of a spatial relationship with reproductive stems in this study has several possible explanations, which are not necessarily mutually exclusive: (1) there is a negative relationship between Brazil nut regeneration and proximity to mother trees, a phenomenon first noted by Janzen (1970) and Connell (1971) for other neotropical species, and proposed as one potential explaining mechanism for Brazil nut distribution by Peres \& Baider (1997); (2) Post-primary dispersers (e.g. spiny rats (Proechimys spp.)) might camouflage the spatial relationship between a parent tree and its progeny (Jansen et al. 2012, Peres \& Baider 1997, Vander Wall et al. 2005); and (3) the mother trees of the juveniles in question are dead, thus explaining why no pattern between adults and juveniles was found.

Many authors have suggested a strong influence of indigenous activity (both deliberate and accidental) on grove maintenance (Ribeiro et al. 2014, Scoles \& Gribel 2011, Shepard \& Ramirez 2011, Thomas et al. 2015). Even so, the size class of interest $(10 \leq \mathrm{dbh}<40 \mathrm{~cm})$ in this study is likely too young for its clustering pattern to be considered a result of deliberate or accidental Amerindian intervention. Amerindian communities along the IOS began to dissipate around a century ago, coinciding with the arrival of rubber tappers in the late 19th and early 20th centuries (Alexiades \& Peluso 2009). And while it is true that the adult populations in our sites are also aggregated, Thomas et al. (2015) have suggested that the regeneration of Brazil nut in Western Amazonia (a region characterized by a sparser pre-Columbian human population than in the Eastern Amazon (McMichael et al. 2012)) seems to have been controlled predominantly by natural processes.

It is likely that other anthropogenic (e.g. historical campsites of Brazil nut harvesters, contemporary agricultural fields) and biophysical processes (e.g. blowdowns) have contributed to the local distribution patterns and densities of this size class in our study sites. The strong peaks of aggregation for juveniles and adult Brazil nuts in this study occurred at long distances (300$900 \mathrm{~m}$ ), pointing to the potential of multiple tree canopy gaps as drivers of spatial patterns, either via natural or anthropogenic sources. In addition to blowdowns, the influence of more contemporary agricultural activities within the concessions could explain the spatial clustering of juveniles, especially in the case of Alegria II (see Figure 2 for depiction of abandoned field in this concession). Other studies have confirmed that planted Brazil nut seedling growth rates are much higher in open areas (e.g. shifting cultivation fields) than in small canopy openings found in undisturbed forest, where light, nutrient and water resources are limited (Cotta et al. 2008, Kainer et al. 1998). The field in this particular concession is $\sim 30$ y old (gradually increasing in size over the last three decades), thus a strong candidate in terms of influencing regeneration and recruitment for the size class in question around the perimeter of the field.

Our data contribute to a more thorough understanding of Brazil nut tree population structure in selectively logged forests in south-western Amazonia, particularly for assessing the status of juvenile trees that represent the future resource base. Even though we found no direct influence of cut stump location on the spatial distribution of juvenile trees, we recognize that the interaction between timber harvests and Brazil nut population dynamics is not static, given the multiple anthropogenic 
drivers (e.g. logging, Brazil nut harvesting, hunting, small-scale agriculture) occurring in these concessions. Indeed, it is unlikely that these drivers will remain fixed in the near future, either as independent or combined factors (Ticktin et al. 2012).

Considering the relative scarcity of Brazil nut juvenile trees in our sites, we also posit that natural regeneration cohorts would benefit from tending (i.e. clearing of competing species around young trees; D'Oliveira 2000, Peña-Claros et al. 2008) to enhance recruitment into the intermediate size classes. Concessionaires already recognize the importance of enrichment planting of Brazil nut, often taking advantage of logging gaps to plant seedlings provided by local NGOs (pers. obs.). This type of informal integration to maintain local Brazil nut tree populations (motivated by cultural as much as economic considerations) is happening on a frequent basis, providing an opportunity to link best management practices for both forest products. Particularly in the case of smallholder forestry in southwestern Amazonia, joint inventories and Brazil nutspecific technical recommendations are still largely absent from timber management plans (Cronkleton et al. 2012, Duchelle et al. 2012). As such, efforts to manage the Brazil nut resource base in the context of multiple forest use is vital to the development of local conservation and socioeconomic goals, and further efforts should be undertaken to focus on the management of non-reproductive trees.

\section{ACKNOWLEDGEMENTS}

MRG and CAR conceived the study. MRG and MM designed the initial phase of the work which was later refined by CAR. CAR led the writing in collaboration with MRG. CAR carried out data analysis and data quality control. EWT was responsible for the initial mapping and distance calculations of Brazil nut trees and logging gaps. The rest of the co-authors collected field data. We appreciate the contributions of P.A. Usca, P.L.A. Gallegos, B.A. de Simplicio, G.C.R. Marques, F.R. Surco, the Asociación de Castañeros de Alegría, the Asociación de Productores de Castaña de Alerta, Ing. M.G. Roca, C.N.A. Mamani, M.A. Quispe, D.N.C. Apaza, S.A. Coaquira, L.A. Huaman, L.C. Leon, A.N.C. Rafael, D.D. Salcedo, R.L.M.C. Puma, J.A.G. Juriuchi, N.G. Quispe, F.L.M. Siani, S.M. Ferro, E.S. Ccalluchi, J. Loja, D.A. Huamantica, M. Aleman, R. Isla, M.D. Bernal and C. Murto. We also thank S. Traissac for his valuable insights and development of the R code for the spatial analyses. Our thanks also to C. Baraloto, C. Klimas, S. Traissac and two anonymous reviewers for providing helpful comments on earlier drafts. This work was funded by the United States Agency for International Development and the CGIAR Research Program on Forests, Trees and Agroforestry.

\section{LITERATURE CITED}

ALEXIADES, M. N. \& PELUSO,D. M. 2009. Plants of the ancestors, plants of the outsiders: Ese Eja history, migration, and medicinal plants. Pp. 220-248 in Alexiades, M. N. (ed.). Mobility and migration in indigenous Amazonia: contemporary ethnoecological perspectives. Berghahn Books, New York. 304 pp.

ASNER, G. P., KELLER, M. \& SILVA, J. N. 2004. Spatial and temporal dynamics of forest canopy gaps following selective logging in the eastern Amazon. Global Change Biology 10:765-783.

ASNER, G. P., KNAPP, D. E., BALAJII, A. \& PÁEZ-ACOSTA, G. 2009. Automated mapping of tropical deforestation and forest degradation: CLASlite. Journal of Applied Remote Sensing 3:033543.

ASNER, G. P., KELLNER, J. R., KENNEDY-BOWDOIN, T., KNAPP, D. E., ANDERSON, C. \& MARTIN, R. E. 2013. Forest canopy gap distributions in the southern Peruvian Amazon. PLoS ONE 8: e60875.

BALÉE, W. 1989. The culture of Amazonian Forest. Advances in Economic Botany 7:1-21.

BLEHER, B. \& BÖHNING-GAESE, K. 2001. Consequences of frugivore diversity for seed dispersal, seedling establishment and the spatial pattern of seedlings and trees. Oecologia 129:385-394.

BRIENEN, R. J. W. \& ZUIDEMA, P. A. 2006. Lifetime growth patterns and ages of Bolivian rain forest trees obtained by tree ring analysis. Journal of Ecology 94:481-493.

CARDÓ, A. A., SEQUEIRA, V. A. S. \& TORRES PADILLA, J. A. 2002. Mejoramiento del sistema de cosecha de castaña (Bertholletia excelsa) en Madre de Dios y sus impactos en la economía del productor castañero. Asociación para la Conservación de la Cuenca Amazónica, Proyecto Conservando Castañales, Puerto Maldonado, Madre de Dios, Peru, $77 \mathrm{pp}$.

CHÁVEZ, A., GUARIGUATA, M. R., CRONKLETON, P., MENTON, M., CAPELLA, J. L., ARAUJO, J. P. \& QUAEDVLIEG, J. 2012. Superposición espacial en la zonificación de bosques en Madre de Dios. CIFOR Infobrief no. 58, Bogor, Indonesia.

CONNELL, J. H. 1971. On the role of natural enemies in preventing competitive exclusion in some marine animals and in rain forest trees. Pp. 298-312 in den Boer, P. J. \& Gradwell, G. R. (eds). Dynamics of populations. PUDOC, Wageningen.

COSSÍO-SOLANO, R. E., GUARIGUATA, M. R., MENTON, M., CAPELLA, J. L., RÍOS, L. \& PEÑA, P. 2011. El Aprovechamiento de Madera en las Concesiones Castañeras (Bertholletia excelsa) en Madre de Dios, Perú: Un Análisis de su Situación Normativa. Documento de Trabajo 56 CIFOR. Bogor, Indonesia.

COTTA, J. N., KAINER, K. A., WADT, L. H. O. \& STAUDHAMMER, C. L. 2008. Shifting cultivation effects on Brazil nut (Bertholletia excelsa) regeneration. Forest Ecology and Management 256:28-35.

CRONKLETON, P., GUARIGUATA, M. R. \& ALBORNOZ, M. A. 2012. Multiple use forestry planning: timber and Brazil nut management in the community forests of Northern Bolivia. Forest Ecology and Management 268:49-56.

DELANEY, M., BROWN, S., LUGO, A. E., TORRES-LEZAMA, A. \& BELLO QUINTERO, N. 1998. The quantity and turnover of dead wood in permanent forest plots in six life zones of Venezuela. Biotropica 30:211. 
D'OLIVEIRA, M. V. N. 2000. Artificial regeneration in gaps and skidding trails after mechanised forest exploitation in Acre, Brazil. Forest Ecology and Management 127:67-76.

DUCHELle, A. E., GUARIGUATA, M. R., LESS, G., ALBORNOZ, M. A. \& CHÁVEZ, A. 2012. Evaluating the opportunities and limitations of Brazil nuts and timber in Western Amazonia. Forest Ecology and Management 268:39-48.

FREDERICKSEN, T. S.\& PUTZ, F.E. 2003. Silvicultural intensification for tropical forest conservation. Biodiversity and Conservation 12:14451453.

GOREAUD, F. \& PÉLISSIER, R. 1999. On explicit formulas of edge effect correction for Ripley's K-function. Journal of Vegetation Science 10:433-438.

GOREAUD, F. \& PÉLISSIER, R. 2003. Avoiding misinterpretation of biotic interactions with the intertype K12-function: population independence vs. random labelling hypotheses. Journal of Vegetation Science 14:681-692.

GRISCOM, B. W.\& ASHTON, P. M. S. 2006. A self-perpetuating bamboo disturbance cycle in a neotropical forest. Journal of Tropical Ecology 22:587-597.

GUARIGUATA, M. R., LICONA, J. C., MOSTACEDO, B. \& CRONKLETON, P. 2009. Damage to Brazil nut trees (Bertholletia excelsa) during selective timber harvesting in Northern Bolivia. Forest Ecology and Management 258:788-793.

HAASE, P. 1995. Spatial pattern analysis in ecology based on Ripley's $K$-function: introduction and methods of edge correction. Journal of Vegetation Science 6:575-582.

HAUGAASEN, T. \& HAUGAASEN, J. M. 2010. Cache pilferage may be prominent in Neotropical forests. Mammalia 74:423-425.

HAugAasen, J. M. T., HAUgAasen, T., PERES, C. A., GRIBEL, R. \& WEGGE, P. 2012. Fruit removal and natural seed dispersal of the Brazil nut tree (Bertholletia excelsa) in Central Amazonia, Brazil. Biotropica 44:205-210.

HERAULT, B., OAULLET, J., BLANC, L., WAGNER, F. \& BARALOTO, C. 2010a. Growth responses of neotropical trees to logging gaps. Journal of Applied Ecology 47:821-831.

HERAULT, B., BEAUCHÊNE, J., MULLER, F., WAGNER, F., BARALOTO, C., BLANC, L. \& MARTIN, J.-M. 2010b. Modeling decay rates of dead wood in a neotropical forest. Oecologia 164:243-251.

HERRERO-JÁUREGUI, C., SIST, P. \& CASADO, M. A. 2012. Population structure of two low-density neotropical tree species under different management systems. Forest Ecology and Management 280: 31-39.

IIAP (Instituto de Investigaciones de la Amazonía Peruana) \& CTAR (Transitorio de Administración Regional Madre de Dios). 2001. Madre de Dios: Camino al Desarrollo Sostenible. Propuestas de Zonificación Ecológica Económica como Base para el Ordenamiento Territorial. IIAP, Lima. 135 pp.

JANSEN, P. A. \& ZUIDEMA, P. A. 2001. Logging, seed dispersal by vertebrates, and natural regeneration of tropical timber trees. Pp. 35-60 in Fimbel, R. A., Grajal, A. \& Robinson, J.G. (eds). The cutting edge: conserving wildlife in logged tropical forests. Columbia University Press, New York.

JANSEN, P. A., HIRSCH, B. T., EMSENS, W. J., ZAMORA-GUTIERREZ, V., WIKELSKI, M. \& KAYS, R. 2012. Thieving rodents as substitute dispersers of megafaunal seeds. Proceedings of the National Academy of Sciences USA 109:12610-12615.

JANZEN, D. H. 1970. Herbivores and the number of tree species in tropical forests. American Naturalist 104:501-528.

JOHN, R., DALLING, J. W., HARMS, K. E., YAVITT, J. B., STALLARD, R. F., MIRABELLO, M., HUBBELL, S. P., VALENCIA, R., NAVARRETE, H., VALLEJO, M. \& FOSTER, R. B. 2007. Soil nutrients influence spatial distributions of tropical tree species. Proceedings of the National Academy of Sciences USA 104: 864-869.

KAINER, K. A., DURYEA, M. L., DE MACEDO, N. C. \& WILLIAMS, K. 1998. Brazil nut seedling establishment and autecology in extractive reserves of Acre, Brazil. Ecological Applications 8:397-410.

KAINER, K. A., WADT, L. H. O. \& STAUDHAMMER, C. L. 2014. Testing a silvicultural recommendation: Brazil nut responses 10 years after liana cutting. Journal of Applied Ecology 51:655-663.

LEDO, A., CONDÉS, S. \& MONTES, F. 2011. Intertype mark correlation function: a new tool for the analysis of species interactions. Ecological Modelling 222:580-587.

MARCON, E., TRAISSAC, S. \& LANG, G. 2013. A statistical test for Ripley's function rejection of Poisson null hypothesis. International Scholarly Research Notices 2013:1-9.

MCMICHAEL, C. H., PIPERNO, D. R., BUSH, M. B., SILMAN, M. R., ZIMMERMAN, A. R., RACZKA, M. F. \& LOBATO, L. C. 2012. Sparse pre-Columbian human habitation in western Amazonia. Science 336:1429-1431.

MOLL-ROCEK, J., GILBERT, M. E. \& BROADBENT, E. N. 2014. Brazil nut (Bertholletia excelsa, Lecythidaceae) regeneration in logging gaps in the Peruvian Amazon. International Journal of Forestry Research 2014: 420764.

MORI, S. A. \& PRANCE, G. T. 1990. Taxonomy, ecology, and economic botany of the Brazil nut (Bertholletia excelsa Humb. and Bonpl: Lecythidaceae). Advances in Economic Botany 8:130-150.

MYERS, G. P., NEWTON, A. C. \& MELGAREJO, O. 2000. The influence of canopy gap size on natural regeneration of Brazil nut (Bertholletia excelsa) in Bolivia. Forest Ecology and Management 127: 119-128.

NATHAN, R. \& MULLER-LANDAU, H. C. 2000. Spatial patterns of seed dispersal, their determinants and consequences for recruitment. Trends in Ecology and Evolution 15:278-285.

NELSON, B. W., KAPOS, V., ADAMS, J. B., OLIVEIRA, W. J. \& BRAUN, O.P.G. 1994. Forest disturbance by large blowdowns in the Brazilian Amazon. Ecology 75:853-858.

NEPSTAD, D., BROWN, I., LUZ, L., ALECHANDRE, A. \& VIANA, V. 1992. Biotic impoverishment of Amazonian forests by rubber tappers, loggers, and cattle ranchers. Advances in Economic Botany 9: $1-14$.

ORTIZ, E. 2002. Brazil nut (Bertholletia excelsa). Pp. 61-74 in Shanley, P., Pierce, A. R., Laird, S. A. \& Guillen, A. (eds). Tapping the green market: certification and management of non-timber forest products. Earthscan, London.

PEÑA-CLAROS, M., FREDERICKSEN, T. S., ALARCÓN, A., BLATE, G. M., CHOQUE, U., LEAÑO, C., LICONA, J. C., MOSTACEDO, B., PARIONA, W., VILLEGAS, Z. \& PUTZ, F. E. 2008. Beyond reduced-impact logging: silvicultural treatments to increase growth rates of tropical trees. Forest Ecology and Management 256:1458-1467. 
PERES, C. A. \& BAIDER, C. 1997. Seed dispersal, spatial distribution and population structure of Brazil nut trees (Bertholletia excelsa) in southeastern Amazonia. Journal of Tropical Ecology 13:595-616.

PERES, C. A., BAIDER, C., ZUIDEMA, P. A., WADT, L. H. O., KAINER, K. A., GOMES-SILVA, D. A. P., SALOMÃO, R. P., SIMÕES, L. L., FRANCIOSI, E. R. N., VALVERDE, F. C., GRIBEL, R., SHEPARD, G. H., KANASHIRO, M., COVENTRY, P., YU, D. W., WATKINSON, A. R. \& FRECKLETON, R. P. 2003. Demographic threats to the sustainability of Brazil nut exploitation. Science 302:2112-2114.

PERZ, S. G., QIU, Y., XIA, Y., SOUTHWORTH, J., MARSIK, M., ROCHA, K., PASSOS, V., ROJAS, D., ALARCÓN, G., BARNES, G. \&BARALOTO, C. 2013. Trans-boundary infrastructure and land cover change: highway paving and community-level deforestation in a tri-national frontier in the Amazon. Land Use Policy 34:27-41.

RIBEIRO, M. B. N., JEROZOLIMSKI, A., DE ROBERT, P., SALLES, N. V., KAYAPÓ, B., PIMENTEL, T. P. \& MAGNUSSON, W. E. 2014. Anthropogenic landscape in southeastern Amazonia: contemporary impacts of low-intensity harvesting and dispersal of Brazil nuts by the Kayapó Indigenous people. PLoS ONE 9: e102187.

RIPLEY, B. D. 1977. Modelling spatial patterns (with discussion). Journal of the Royal Statistical Society. Series B (Methodological) 39:172-212.

ROCKWELL, C. A., GUARIGUATA, M. R., MENTON, M., QUISPE, E. A., QUAEDVLIEG, J., WARREN-THOMAS, E., SILVA, H.F., ROJAS, E. E. J., ARRUNATEGUI, J. A. H. K., VEGA, L. A. M., VERA, O. R., HANCCO, R. Q., TITO, J. F. V., PANDURO, B. T. V. \& SALAS, J. J. Y. 2015. Nut production in Bertholletia excelsa across a logged forest mosaic: implications for multiple forest use. PLOS ONE 10(8): e0135464.

SALOMÃO, R. P. 1991. Estrutura e densidade de Bertholletia excelsa H. and B. ("Castanheira”) nas regiões de Carajás e Marabá, Estado do Pará. Boletim do Museu Paraense Emilio Goeldi. Serie Botânica 7: 47-68.

SCHÖNGART, J., GRIBEL, R., FERREIRA DA FONSECA-JUNIOR, S. \& HAUGAASEN, T. 2015. Age and growth patterns of Brazil nut trees (Bertholletia excelsa Bonpl.) in Amazonia, Brazil. Biotropica 47:550558.

SCOLES, R. \& GRIBEL, R. 2011. Population structure of Brazil nut (Bertholletia excelsa, Lecythidaceae) stands in two areas with different occupation histories in the Brazilian Amazon. Human Ecology 39:455-464.

SCOLES, R. \& GRIBEL, R. 2012. The regeneration of Brazil nut trees in relation to nut harvest intensity in the Trombetas River valley of Northern Amazonia, Brazil. Forest Ecology and Management 265:7181.

SCOLES, R. \& GRIBEL, R. 2015. Human influence on the regeneration of the Brazil nut tree (Bertholletia excelsa Bonpl., Lecythidaceae) at Capanã Grande Lake, Manicoré, Amazonas, Brazil. Human Ecology 43:843-854.

SHEPARD, G. H. \& RAMIREZ, H. 2011. "Made in Brazil": human dispersal of the Brazil nut (Bertholletia excelsa, Lecythidaceae) in ancient Amazonia. Economic Botany 65:44-65.

SORIANO, M., KAINER, K. A., STAUDHAMMER, C. L. \& SORIANO, E. 2012. Implementing multiple forest management in Brazil nut-rich community forests: effects of logging on natural regeneration and forest disturbance. Forest Ecology and Management 268:39-48.

STAUDHAMMER, C.L., WADT, L. H. O.\& KAINER, K. A. 2013. Tradeoffs in basal area growth and reproduction shift over the lifetime of a longlived tropical species. Oecologia 173:45-57.

SWAINE, M. D. \& HALL, J. B. 1987. Early succession on cleared forest land in Ghana. Journal of Ecology 71:601-627.

SWAINE, M. D., HALL, J. B. \& ALEXANDER, I. J. 1987. Tree population dynamics at Kade, Ghana (1968-82). Journal of Tropical Ecology 3:331-345.

TERBORGH, J., FLORES N, C., MUELLER, P. \& DAVENPORT, L. 1997. Estimating the ages of successional stands of tropical trees from growth increments. Journal of Tropical Ecology 13:833-856.

THOMAS, E., ALCÁZAR CAICEDO, C., LOO, J. \& KINDT, R. 2014. The distribution of the Brazil nut (Bertholletia excelsa) through time: from range contraction in glacial refugia, over human-mediated expansion, to anthropogenic climate change. Boletim do Museu Paraense Emílio Goeldi. Ciências Naturais 9:267-291.

THOMAS, E., ALCÁZAR CAICEDO, C., MCMICHAEL, C. H., CORVERA, R. \& LOO, J. 2015. Uncovering spatial patterns in the natural and human history of Brazil nut (Bertholletia excelsa) across the Amazon Basin. Journal of Biogeography 42:1367-1382.

TICKTIN, T. 2004. The ecological implications of harvesting non-timber forest products. Journal of Applied Ecology 41:11-21.

TICKTIN, T., GANESAN, R., PARAMESHA, M. \& SETTY, S. 2012. Disentangling the effects of multiple anthropogenic drivers on the decline of two tropical dry forest trees. Journal of Applied Ecology 49:774-784.

TOBLER, M. W., CARRILLO-PERCASTEGUI, S. E. \& POWELL, G. 2009. Habitat use, activity patterns and use of mineral licks by five species of ungulate in south-eastern Peru. Journal of Tropical Ecology 25:261270.

TRAISSAC, S. \& PASCAL, J.-P. 2014. Birth and life of tree aggregates in tropical forest: hypotheses on population dynamics of an aggregated shade-tolerant species. Journal of Vegetation Science 25: 491-502.

VANDER WALL, S., FORGET, P.-M., LAMBERT, J. E. \& HULME, P. E. 2005. Seed fate pathways: filling the gap between parent and offspring. Pp. 1-8 in Forget, P.-M., Lambert, J., Hulme, P. \& Vander Wall, S. (eds). Seed fate: predation, dispersal and seedling establishment. CABI Publishing, Wallingford.

WADT, L. H. O., KAINER, K. A. \& GOMES-SILVA, D. A. P.2005. Population structure and nut yield of a Bertholletia excelsa stand in Southwestern Amazonia. Forest Ecology and Management 22:371384.

ZUIDEMA, P. A. 2003. Ecology and management of the Brazil nut tree (Bertholletia excelsa), PROMAB (Programa Manejo de Bosques de la Amazonia Boliviana) Scientific Series 6. PROMAB, Riberalta, Bolivia. ZUIDEMA, P. A. \& BOOT, R. G. A. 2002. Demography of the Brazil nut tree (Bertholletia excelsa) in the Bolivian Amazon: impact of seed extraction on recruitment and population dynamics. Journal of Tropical Ecology 18:1-31. 